\title{
Callus Proliferation from Immature Leaf Explants of Durian (Durio zibethinus Murr. cv. Selat) with the Addition of Picloram and BAP
}

\author{
Zulkarnain $^{1^{*}}$, Neliyati ${ }^{1}$, and Lizawati ${ }^{1}$ \\ Diterima 20 Agustus 2013/Disetujui 29 Oktober 2013
}

\begin{abstract}
This study was aimed to obtain an appropriate medium composition with various combinations of Picloram + BAP for the proliferation of embryogenic callus from immature leaf explants of durian. The experiment was carried out at the Plant Biotechnology Laboratory, Faculty of Agriculture, the University of Jambi from January through to November 2012. Five levels of Picloram (1.0, 2.0, 3.0, 4.0, $5.0 \mathrm{mg} \mathrm{L}^{-1}$ ) in combination with three levels of $B A P\left(0,0.5,1.5 \mathrm{mg} \mathrm{L}^{-1}\right)$ were tested. Therefore, there were 15 treatment combinations with 4 replicates resulting in 60 experimental unit. Each unit consisted of 4 culture flasks containing one immature leaf explant. Cultures were kept in culture room with $16 \mathrm{~h}$ photoperiod and 1000 lux light intensity. The results showed that: 1) callus proliferation on immature leaf explants of durian $\mathrm{cv}$. Selat was dependent upon the level of Picloram + BAP added to culture medium, 2) the addition of 3.0 - 5.0 $m g L^{-1}$ Picloram without BAP was found to be effective in promoting callus proliferation on the majority of cultured explants, 3) all regenerated callus showed similar characteristics, but embryogenic properties was not seen yet, and 4) the application of tissue culture technique in the propagation of durian cv. Selat needs further comprehensive investigation, particularly on factors directly affecting culture development and inducing somatic embryogenesis.
\end{abstract}

Key words: tissue culture, in vitro culture, micropropagation, plant hormones, auxin, cytokinin, fruit crops.

\begin{abstract}
ABSTRAK
Penelitian ini bertujuan untuk mendapatkan komposisi media yang tepat dari kombinasi Picloram + BAP untuk proliferasi kalus embriogenik dari eksplan daun dewasa durian. Penelitian dilakukan di Laboratorium Bioteknologi Tanaman, Fakultas Pertanian, Universitas Jambi dari Januari hingga November 2012. Perlakuan kombinasi media zat pengatur tumbuh adalah lima taraf Picloram $\left(1.0,2.0,3.0,4.0,5.0 \mathrm{mg} \mathrm{L}^{-1}\right)$ dengan kombinasi tiga taraf perlakuan BAP $(0,0.5,1.5 \mathrm{mg}$ $\left.\mathrm{L}^{-1}\right)$. Terdapat 15 kombinasi media perlakuan dengan 4 ulangan, sehingga terdapat 60 kombinasi satuan percobaan. Setiap unit percobaan terdapat 4 botol kultur dengan satu eksplan daun. Kultur disimpan di ruang kultur selama 16 jam penyinaran dan intensitas cahaya 1000 lux. Hasil penelitian menunjukkan bahwa: 1) Proliferasi kalus dari eksplan daun muda buah durian tergantung pada taraf kombinasi picloram + BAP yang ditambahkan ke media kultur; 2) Penambahan 3.0-5.0 mg L $\mathrm{L}^{-1}$ Picloram tanpa BAP memberikan hasil yang efektif untuk menginduksi proliferasi kalus pada sebagian besar eksplan; 3) Regenerasi kalus menunjukkan karakteristik serupa, tetapi embriogenik kalus tidak muncul, dan 4) Perbanyakan eksplan daun durian dengan tehnik kultur jaringan membutuhkan penelitian lebih lanjut, terutama pada faktor yang berpengaruh langsung pada induksi embriogenesis somatik.
\end{abstract}

Kata kunci: auksin, buah, kultur jaringan, kultur in vitro, mikropropagasi, sitokinin, zat pengatur tumbuh,

\footnotetext{
${ }^{1}$ Department of Agroecotechnology Agricultural Faculty The University of Jambi, Kampus Pinang Masak, Mendalo Darat - Jambi 36361, Fax: (0741) 582781, Email: zulkarnain@unja.ac.id / dr.zulkarnain@yahoo.com (*corresponding author)
} 


\section{INTRODUCTION}

Jambi is one of provinces in Indonesia where various horticultural crops, including durian (Durio zibethinus Murr.), are planted and developed. A number of durian germplasms have been recognized as potential varieties in this province, one of them has been the Selat cultivar that was released by the Minister of Agriculture in 2005 as a national durian variety. High economic value of durian cv. Selat fruit is for its sweet, dry, smooth, and moderately odoured flesh. The annual production may reach 170 - 200 fruits per season.

The propagation of durian so far is through generative propagation using seed or vegetatively by cutting or grafting. These methods of propagation is subjected to limited availability of stock plant materials as well as resulted propagules. In addition, the properties of resulted propagules may be different from their mother due to the occurrence of genetic variation when durian is propagated by seed.

Plant biotechnology offers new methodology in enhancing the production of great amount of quality seeds continuously, i.e. via tissue culture technique. Plant propagation by this technique can be done through the induction of organogenesis and/or somatic embryogenesis. The induction of somatic embryogenesis is the most prospective method because it can result in great amount of uniform propagules within a short period of time.

Research on somatic embryogenesis had been done on various plant species such as garlic (Luciani et al., 2006), Dioscorea alata (Belarmino and Gonzales, 2008), peach (de-Alencar Maciel et al., 2010), Agapanthus praecox ssp. minimus (Yaacob et al., 2012), cocoa (Quainoo and Dwomo, 2012), and citrus (Widoretno et al., 2013). Somatic embryogenesis had also been success-fully applied on Alstroemeria (Khaleghi et al. 2008), Dianthus caryophyllus (Karami et al., 2007; Ali et al., 2008) and Bauhinia variegata (Banerjee et al., 2012). Moreover, reports on somatic embryogenesis has been found also on coffea (Neuenschwander and Baumann, 1992; Priyono, 1993; Sreenath et al., 1995), but the rate of success was relatively low and plantlets regeneration was found to be difficult.

Meanwhile, report on durian propagation via tissue culture has also been very limited. Effort of Suharti (2002) only resulted in white and friable callus which grew rapidly on MS medium supplemented with 2,4-D + BAP. Following subcultured on MS medium containing to $5 \mathrm{mg}$ $\mathrm{L}^{-1} \mathrm{BAP}$ the resulted callus showed no response leading to organ or embryo formation. For this reason, it is worthwhile to carry out further research on the induction of somatic embryogenesis on durian for the production of large number of quality seedlings continuously. And as such, this study was aimed at producing a technique (protocol) for rapid mass propagation of durian cv Selat to produce uniform seedling in short time.

\section{MATERIALS AND METHODS}

This investigation was carried out at the Plant Biotechnology Laboratory, Faculty of Agriculture, University of Jambi from February through to November 2012. The culture medium used in the study was Woody Plant Medium (WPM) (Lloyd and Mc Cown, 1980) supplemented with vitamins and $30 \mathrm{~g} \mathrm{~L}^{-1}$ sucrose, and $\mathrm{pH}$ was adjusted to $5.6 \pm 0.2$. To solidify the medium we used $8 \mathrm{~g} \mathrm{~L}^{-1}$ Bacto Agar. The treatments were picloram concentrations (1.0, 2.0, $3.0,4.0,5.0 \mathrm{mg} \mathrm{L}^{-1}$ ) in combination with BAP concentrations $\left(0.0,0.5,1.0 \mathrm{mg} \mathrm{L}^{-1}\right)$. Therefore, there were 15 treatment combinations, each repeated 4 times resulted in 60 experimental units in a Simple Completely Randomized Design. Each experimental unit consisted of 4 culture flasks containing one immature leaf segment explants each.

Stock plant used was durian (Durio zibethinus Murr. cv. Selat) obtained from the Selat Village, Muaro Jambi Regency (Stock Plant Identity No: PI/DR/L/XVIII/3344). Explants were taken from immature leaves and petioles. Sterilization was carried out by rinsing the leaves under tap water, followed by dipping in $2 \%$ antibacterial (Agrept) and $2 \%$ antifungus (Benlate) solutions for 30 minutes, then rinsed three times with sterile water, followed by stratified sterilization in $1.5 \% \mathrm{NaClO}$ for 30 minutes, $1.0 \%$ for 10 minutes and $0.5 \%$ for 5 minutes. Explants were then rinsed in sterile water, and wounded parts were cut before being inoculated on to culture medium.

The culture flasks were kept for a week in a dark room with temperature of $25 \pm 1{ }^{\circ} \mathrm{C}$, then incubated under 1000 lux of light intensity for a period of 16 hours per day. Observation was made for 12 weeks of culture. Variables observed were 
the number of explants forming callus, time to callus formation following culture initiation, callus characteristics (colour, structure and texture), and the percentage of callus showing embryogenic properties. The embryogenic properties of callus was examined under a light microscope.

Quantitative data were analyzed by ranking of mean method and presented in the form of tables and graphics, whereas qualitative data were presented visually in the form of picture/ photograph.

\section{RESULTS AND DISCUSSION}

\section{The effect of Picloram + BAP on growth response}

In general, the cultured young leaf explants showed growth response indicated by callus proliferation on the surface of wounded region. The percentage of explants showing growth response is presented in Table 1.

Table 1 indicates that either Picloram or BAP affects the growth of cultured explants, and thus resulting in callus proliferation. This study also revealed that the higher the concentration of Picloram or BAP, the higher the percentage of explants showing growth response (Figure 1A,B).

Table 1. The effect of picloram + BAP on the percentage of explants showing growth response.

\begin{tabular}{cccc}
\hline \multirow{2}{*}{$\begin{array}{c}\text { Picloram } \\
\left(\mathrm{mg} \mathrm{L}^{-1}\right)\end{array}$} & 0.0 & 0.5 & 1.0 \\
\cline { 2 - 4 } & $12.50 \pm 12.50$ & $43.75 \pm 20.73$ & $18.75 \pm 20.73$ \\
1.0 & $12.50 \pm 12.50$ & $18.75 \pm 20.73$ & $62.50 \pm 21.65$ \\
2.0 & $31.25 \pm 20.73$ & $31.25 \pm 20.73$ & $43.75 \pm 10.83$ \\
3.0 & $43.75 \pm 32.48$ & $68.75 \pm 27.24$ & $75.00 \pm 17.68$ \\
4.0 & $56.25 \pm 20.73$ & $81.25 \pm 20.73$ & $62.50 \pm 27.95$ \\
5.0 & & & \\
\hline
\end{tabular}

\pm Standard Deviation

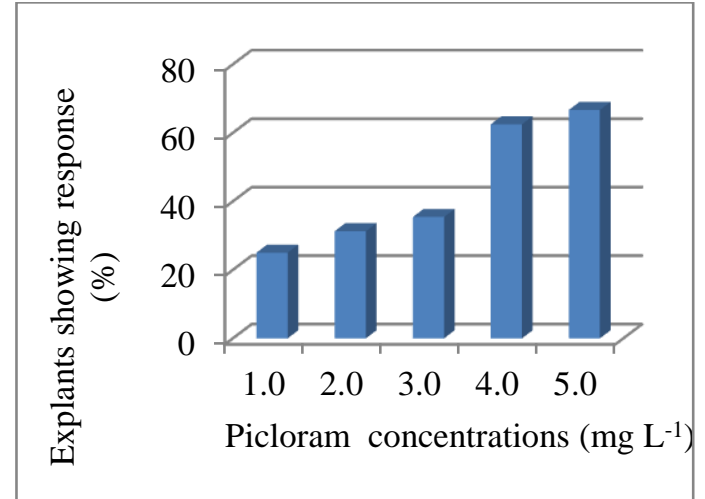

(A)

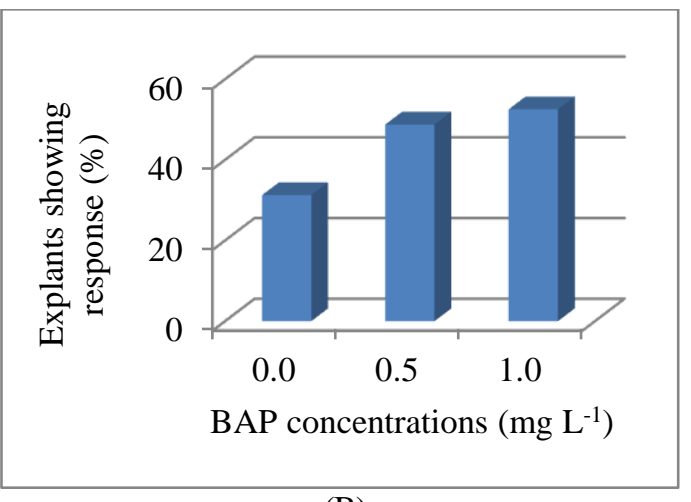

(B)

Figure 1. The effect of various concentrations of Picloram (A) and BAP (B) on the percentage of explants showing growth response.

\section{The effect of Picloram + BAP on the Number of Explants Forming Callus}

The responsive explants continued regenerating callus mass on their surface following 4 weeks of culture initiation. However, some explants did not show any callus proliferation although they did not die and remain fresh till the end of study period. The percentage of explants forming callus is presented in Table 2.

Table 2. The effect of picloram + BAP on the percentage of explants regenerating callus.

\begin{tabular}{ccrr}
\hline \multirow{2}{*}{$\begin{array}{c}\text { Picloram } \\
\left(\mathrm{mg} \mathrm{L}^{-1}\right)\end{array}$} & \multicolumn{3}{c}{$\mathrm{BAP}\left(\mathrm{mg} \mathrm{L}^{-1}\right)$} \\
\cline { 2 - 4 } & 0.0 & \multicolumn{1}{c}{0.5} & \multicolumn{1}{c}{1.0} \\
\hline 1.0 & $00.00 \pm 00.00$ & $18.75 \pm 10.83$ & $6.25 \pm 10.83$ \\
2.0 & $37.50 \pm 37.50$ & $00.00 \pm 00.00$ & $00.00 \pm 00.00$ \\
3.0 & $18.75 \pm 20.73$ & $31.25 \pm 10.83$ & $00.00 \pm 00.00$ \\
4.0 & $18.75 \pm 20.73$ & $6.25 \pm 10.83$ & $6.25 \pm 10.83$ \\
5.0 & $25.00 \pm 30.62$ & $00.00 \pm 00.00$ & $00.00 \pm 00.00$ \\
\hline
\end{tabular}


The above mentioned table shows that the application of Picloram up to $3.0 \mathrm{mg} \mathrm{L}^{-1}$ enhances callus formation on responsive explants $(16,67 \%)$, whereas at concentration beyond $3.0 \mathrm{mg} \mathrm{L}^{-1}$ Picloram is found to inhibit callus proliferation (Figure 2A). Meanwhile, the presence of BAP in culture medium is found to suppress callus proliferation. This is indicated by the higher the concentration of BAP, the fewer the percentage of explants forming callus (Figure 2B).

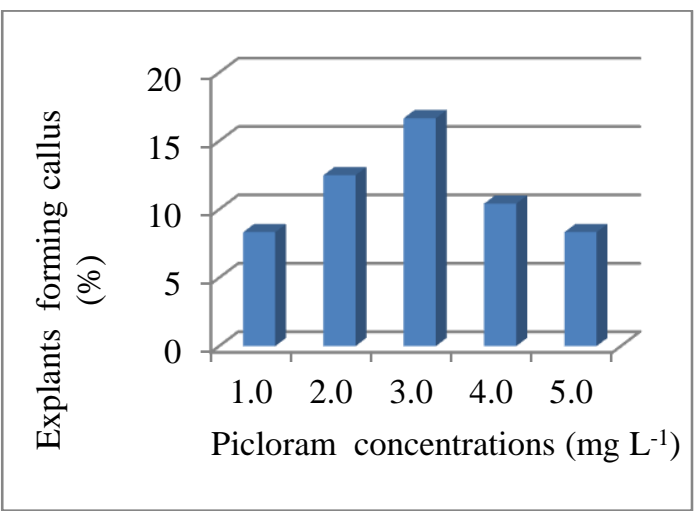

(A)

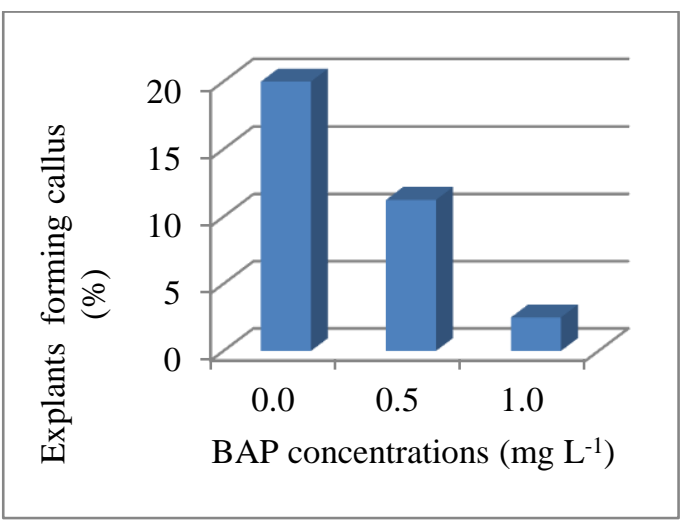

(B)

Figure 2. The effect (A) Picloram and (B) BAP concentration on the percentage of explants forming callus.

\section{The Effect of Picloram + BAP on the Time to Callusing Following Culture Initiation}

Though all explants showed growth response upon culture, some of them did not show any callus proliferation. Callus started to proliferate within 34 - 43 days after culture initation. The average time required to grow callus under various concentration of Picloram $+\mathrm{BAP}$ is presented in Table 3.
Tabel 3. The effect of picloram + BAP on the time required to grow callus (days after culture initiation)

\begin{tabular}{cccc}
\hline \multirow{2}{*}{$\begin{array}{c}\text { Picloram } \\
\left(\mathrm{mg} \mathrm{L}^{-1}\right)\end{array}$} & \multicolumn{3}{c}{$\mathrm{BAP}\left(\mathrm{mg} \mathrm{L}^{-1}\right)$} \\
\cline { 2 - 4 } & 0.0 & 0.5 & 1.0 \\
\hline 1.0 & - & 39.0 & 43.0 \\
2.0 & 36.8 & - & - \\
3.0 & 39.3 & 34.5 & - \\
4.0 & 38.5 & 34.0 & 34.0 \\
5.0 & 38.7 & - & - \\
\hline
\end{tabular}

Data presented in Table 3 reveals that the presence of Picloram in culture medium enhances callus proliferation from durian young leaf explants. The fastest callus proliferation was found on medium supplemented with $4.0 \mathrm{mg} \mathrm{L}^{-1}$ Picloram (35.5 days following culture initiation) as shown in Figure 3A. Similarly, by the addition of $0.5 \mathrm{mg} \mathrm{L}^{-1} \mathrm{BAP}$, the average time required to grow callus 35.8 days after initiation (Figure 3B), which is the fastest among BAP concentration tested.

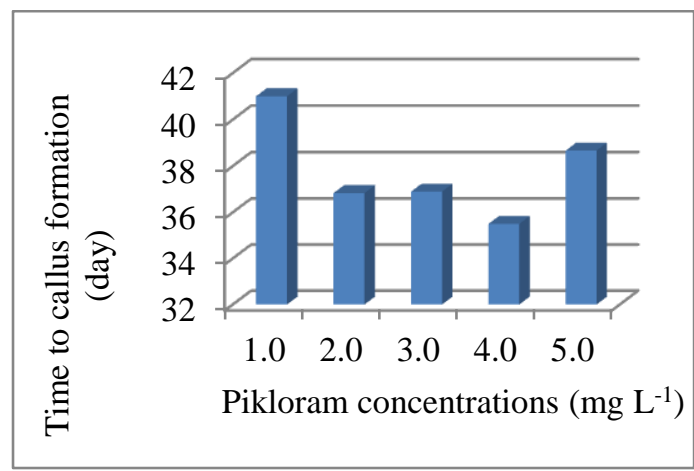

(A)

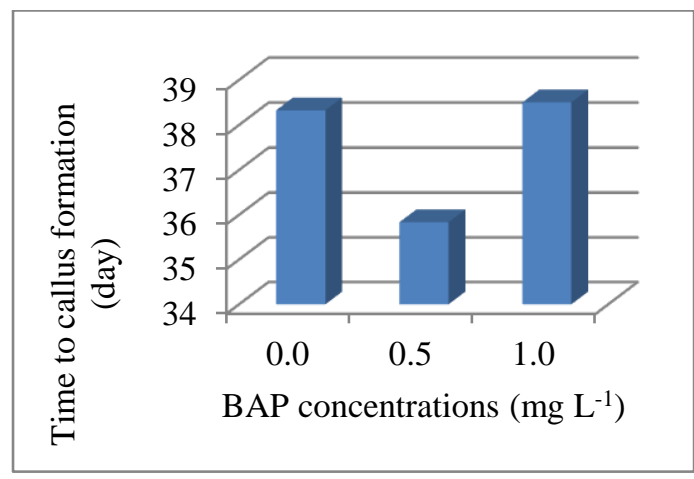

(B)

Figure 3. The effect of various concentrations of picloram (A) and BAP (B) on the time to callusing following culture initiation 
The effect of Picloram + BAP on the Characteristics of Regenerated Callus

In general, callus proliferated from the surface of explants cultured on different combination of picloram + BAP showed similar characteristics. They are white-yellowish to yellow-brownish in colour and mostly friable in structure (Table 4).

Tabel 4. The effect of picloram + BAP on the colour and structure of regenerated callus

\begin{tabular}{|c|c|c|c|}
\hline \multirow{2}{*}{$\begin{array}{l}\text { Picloram } \\
\left(\mathrm{mg} \mathrm{L}^{-1}\right)\end{array}$} & \multicolumn{3}{|c|}{$\operatorname{BAP}\left(\mathrm{mg} \mathrm{L}^{-1}\right)$} \\
\hline & 0.0 & 0.5 & 1.0 \\
\hline 1.0 & - & $\begin{array}{c}\text { White } \\
\text { yellowish } \\
\text { and } \\
\text { friable }\end{array}$ & $\begin{array}{c}\text { White } \\
\text { yellowish } \\
\text { and } \\
\text { compact }\end{array}$ \\
\hline 2.0 & $\begin{array}{l}\text { White and } \\
\text { friable }\end{array}$ & - & - \\
\hline 3.0 & $\begin{array}{c}\text { White } \\
\text { yellowish, } \\
\text { green } \\
\text { brownish } \\
\text { and friable }\end{array}$ & $\begin{array}{c}\text { White } \\
\text { yellowish, } \\
\text { brownish } \\
\text { and } \\
\text { friable }\end{array}$ & - \\
\hline 4.0 & $\begin{array}{l}\text { White and } \\
\text { friable }\end{array}$ & $\begin{array}{l}\text { White } \\
\text { and } \\
\text { friable }\end{array}$ & $\begin{array}{l}\text { White } \\
\text { and } \\
\text { friable }\end{array}$ \\
\hline 5.0 & $\begin{array}{c}\text { White } \\
\text { yellowish, } \\
\text { friable and } \\
\text { few } \\
\text { compact }\end{array}$ & - & - \\
\hline
\end{tabular}

The response showed by explants cultured under in vitro system is not always the same one among another, and much depend upon the type of explants used, enviromental conditions, medium composition, and the presence of plant growth regulators - particularly auxin and cytokinin - in culture medium. The combination of two or more of such factors often becoming critical factor and very crucial in inducing and promoting growth response from cultured explants. Laslo and Vicas (2008) suggested that the direction of explant growth and development was very much influenced by the ratio of endogenuous against exogenuous growth regulators. In addition, Winarto et al. (2010) claimed that the incorporation of exogenuous growth regulators into culture medium might affect the activity of those hormones already presence within cultured tissues. Therefore, it is important to pay serious attention to the types and concentrations of exogenuous plant growth regulators applied to culture medium for inducing growth and development of explant to the desired direction.

Callus proliferation on the surface and/or from within the cultured explants is one of growth and development responses frequently found under in vitro culture system. Gamborg and Shyluk (1981) suggested that in vitro callus regeneration was a consequency of irregular development of unspecialized cells and lost of structures within organized cells. In our study, the percentage of explant forming callus was higher when they were cultured on medium supplemented with $2.0 \mathrm{mg} \mathrm{L}^{-1}$ Picloram without BAP $(37.50 \%$ exsplants forming callus). This indicates that the presence of Picloram in culture medium is critical in stimulating callus proliferation on cultured tissues.

The use of exogenuous growth regulators is important for the optimalization of in vitro callus induction (Lim et al., 2009). Our study revealed that callus proliferation took place with in 6 weeks following culture initiation. The fastest callus proliferation occurred on $4.0 \mathrm{mg} \mathrm{L}^{-1}$ Picloram plus $0.5-1.0 \mathrm{mg} \mathrm{L}^{-1}$, i.e. 34 days after culture initiation. Callus started to proliferate from the wounded part of explants (around wounded surface) and continued growing and covering the whole explant surface.

The proliferated callus were white-yellowish or white-greenish in colour and friable (few compact) in structure (Figure 4). This indicates that the proliferated callus has a potency to express their embryogenic properties when subcultured on appropriate medium, and develop complete somatic embryos. Callus with similar characteristics which then developed into white compact callus, before eventually regenerated green globular structures, were also reported by Sha-Valli-Khan et al. (2002) in tissue culture of Bixa arellana. The formation of such globular green structures was an initial symptom of embryogenesis as found by Sudhersan and AboEl Nil (2002) and Zulkarnain (2003) in Swainsona formosa micropropagation. However, the development of callus reported here had not show any sign to somatic embryo formation yet. This is presumably due to the time to observe further explant development was very short as well as the involvement of other factors are required to induce embryogenic capacity of callus. 


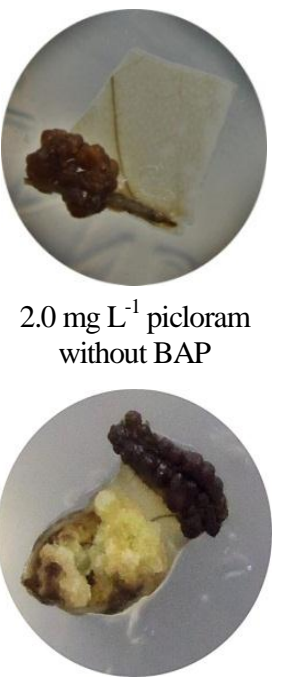

$4.0 \mathrm{mg} \mathrm{L}^{-1}$ picloram without BAP

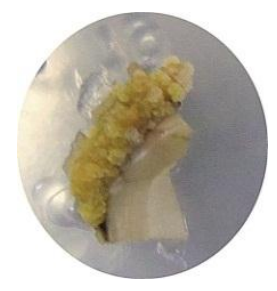

$1.0 \mathrm{mg} \mathrm{L}^{-1}$ picloram + $0.5 \mathrm{mg} \mathrm{L}^{-1} \mathrm{BAP}$

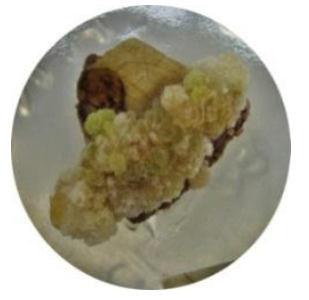

$3.0 \mathrm{mg} \mathrm{L}^{-1}$ picloram without BAP

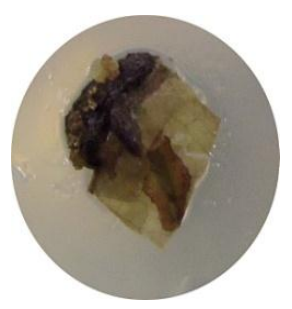

$5.0 \mathrm{mg} \mathrm{L}^{-1}$ picloram without BAP

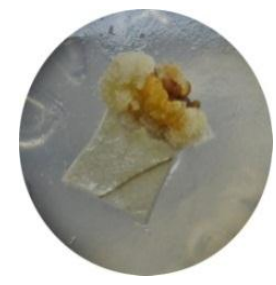

$3.0 \mathrm{mg} \mathrm{L}^{-1}$ picloram + $0.5 \mathrm{mg} \mathrm{L}^{-1} \mathrm{BAP}$

Figure 4. The characteristics of callus proliferated from young leaf of durian cv. Selat cultured on WPM basal medium supplemented with Picloram with and without BAP.

The effort of obtaining embryogenic callus may be done by modifying a number of environmental factors, particularly medium composition. In addition, the proliferated callus mass must be subcultured onto new fresh medium to avoid water and nutrient deficiency due to prolonged culture in the same medium. Therefore, subculture is becoming a crucial step to maintain the sustainable live of callus mass and as such. Dodds and Robert (1985) suggested to carry out subculture for callus sizing $5-10 \mathrm{~mm}$ or $20-100$ $\mathrm{mg}$ weight in order to obtain rapid growth on new medium. Subculture may also be done every 28 days (2 - 6 weeks). Nevertheless, the appropriate time to shift the culture depends on the speed of callus growth.

The results of this investigation shows a great chance to produce embryogenic callus from young leaf explants of durian cv. Selat by the addition of growth regulators, particularly 3.0 to $5.0 \mathrm{mg} \mathrm{L}^{-1}$ Picloram in combination with 1.0 to $3.0 \mathrm{mg} \mathrm{L}^{-1}$ BAP. It is hoped that by this tissue culture technique, the effort of producing large number of uniform and pathogen-free durian seedling may be realized. Taji et al. (2002) suggested that somatic embryogenesis was very much important in tissue culture technique aiming at plant propagation. However, this proses is restricted by many factors as somatic embryos will only develop from within embryogenic callus mass, and producing callus with embryogenic properties is sometimes took longer time. Besides, other factors such as plant hormones, nutrients and environmental conditions need to optimized before embryogenesis can take place.

\section{CONCLUSION}

Based on the results of this investigation it can be concluded that: The induction of callus proliferation on immature leaf explants of durian $\mathrm{cv}$. Selat under in vitro sistem was affected by the concentrations of Picloram and/or BAP applied to culture medium. Among the concentrations tested, 3.0 - $5.0 \mathrm{mg} \mathrm{L}^{-1}$ Picloram without BAP were found to enhance callus proliferation on the majority of cultured explants. All callus regenerated in this investigation showed similar characteristics, but embryogenic properties had not yet revealed, though there were indications of embryogenic symptoms. The application of tissue culture technique on vegetative propagation of durian cv. Selat needs further and comprehensive investigation, especially on factors directly influence the induction of somatic embryogenesis.

\section{ACKKNOWLEDGEMENT}

The authors would like to thanks The Directorate of Research and Community Service Directorate General of Higher Eduction The Ministry of Education and Culture for financial support of this study through Penelitian Unggulan Perguruan Tinggi scheme financial year 2012. 


\section{BIBLIOGRAPHY}

Ali, A., H. Afrasiab, S. Naz, M. Rouf, J. Iqbal. 2008. An efficient protocol for in vitro propagation of carnation (Dianthus caryophyllus). Pakistan J. Botany 40: 111121.

Banerjee, P., S. Maity, N. Banerjee. 2012. High frequency somatic embryogenesis and plantlet regeneration of Bauhinia variegata, a multipurpose tree legume. Indian Journal of Fundamental and Applied Life Sciences. 2: 87-95.

Belarmino, M.M., J.R. Gonzales. 2008. Somatic embryogenesis and plant regeneration in purple food yam (Dioscorea alata L.). Annals Trop. Res. 30: 22-33.

de-Alencar, M.S., P.C.P.F. Junior, R.A. da-Silva, J.E. $\quad$ Scherwinski-Pereira. 2010. Morphoanatomical characterization of embryogenic calluses from immature zygotic embryo of peach palm during somatic embryogenesis. Acta Scientiarum. 32: 263-267.

Dodds, J.H., L.W. Roberts. 1985. Experiments in Plant Tissue Culture. Cambridge University Press, Cambridge.

Gamborg, O.L., J.P. Shyluk. 1981. Nutrition, media and characteristic of plant cell and tissue culture. p. 21-44. Dalam T.A. Thorpe [ed.], Plant Tissue Culture: Method and Application in Agriculture. Academic Press, Inc., New York.

Karami, O., M. Esna-Ashari, K. Piri, P. Almasi. 2007. Efficient regeneration of carnation (Dianthus caryophyllus L.) via somatic embryogenesis. Propagation of Ornamental Plants. 7: 3-8.

Khaleghi, A., A. Khalighi, P. Azadi, M. Mii. 2008. Induction of embryogenic callus and plant regeneration from nodes of greenhouse grown plants of Alstroemeria cv. Fuego. Journal of Food, Agriculture and Environment. 6: 374-377.

Laslo, V., S. Vicaș. 2008. The influence of certain phytohormones on organogenesis process for in vitro culture of apricot (Armeniaca vulgaris). Analele Universităţii din Oradea, Fascicula: Protecţia Mediului. 13: 200205.

Lim, Z.X., A.P.K. Ling, S. Hussein. 2009. Callus Induction of Ocimum sanctum and estimation of its total flavonoids content. Asian J. Agric. Sci. 1: 55-61.

Lloyd, G.B., B.H. McCown. 1980. Commercially feasible micropropagation of mountain laurel (Kalmia latifolia) by use of shoot tip culture. Proceedings of the International Plant Propagators' Society. 30: 412-427.

Luciani, G.F., A.K. Mary, C. Pellegrini, N.R. Curvetto. 2006. Effects of explants and growth regulators in garlic callus formation and plant regeneration. Plant Cell, Tissue and Organ Culture. 87: 139143.

Neuenschwander, B., T.W. Baumann. 1992. A novel type of somatic embryogenesis in Coffea arabica. Plant Cell Report. 10: 608612.

Priyono. 1993. Embriogenesis somatik langsung pada kultur in vitro eksplan daun kopi arabika (Coffea arabica). J. Pertanian Indonesia. 3: 16-20.

Quainoo, A. K., B. I. Dwomo. 2012. The effect of TDZ and 2,4-D concentrations on the induction of somatic embryo and embryogenesis in different cocoa genotypes. J. Plant Studies. 1: 72-78.

Sha-Valli-Khan, P.S., E. Prakash, K.R. Rao. 2002. Callus induction and plantlet regeneration in Bixa arellana L., an annatto-yielding tree. In Vitro Cellular and Developmental Biology-Plant. 38: 186200.

Sreenath, H.L., H.M. Shanta, K.H. Babu, M.M. Naidu. 1995. Somatic embryogenesis from integument (perisperm) cultures of coffee. Plant Cell Report. 14: 670-673.

Sudhersan, C., M. Abo El-Nil. 2002. Somatic embryogenesis on Sturt's desert pea (Swainsona 
J. Hort. Indonesia 4(3): 107-114. Desember 2013.

formosa). Scientific Correspondence. 83: 1074-1076.

Suharti, N. 2002. Penggunaan bebeberapa senyawa anti jamur dan bakteri dalam mengantisipasi kontaminasi pada kultur in vitro tanaman durian. Laporan Penelitian Lembaga Penelitian Universitas Andalas, Padang (in Indonesian).

Taji, A., P. Kumar, P. Lakshmanan. 2002. In Vitro Plant Breeding. Haworth Press, Inc., New York.

Widoretno, W., C. Martasari, F.D. Nirmala. 2013. Pengaruh sukrosa dan fotoperiode terhadap embriogenesis somatik jeruk Keprok Batu 55 (Citurs reticulata Blanco.). J. Hort. Indonesia. 4(1): 44-53.
Winarto, B., N.A. Mattjik, A. Purwito, B. Marwoto. 2010. Aplikasi 24-D dan TDZ pada regenerasi kalus dari anther Anthurium. Jurnal Hortikultura. 20: 1-9.

Yaacob, J.S., A.I.M. Yussof, R.M. Taha, S. Mohajer. 2012. Somatic embryogenesis and plant regeneration from bulb, leaf and root explants of African blue lily (Agapanthus praecox ssp. minimus). Australian J. Crop Sci. 6: 1462-1470.

Zulkarnain. 2003. Breeding strategies in Sturt"s Desert Pea (Swainsona formosa (G.Don) J. Thompson) using in vitro and in vivo techniques. Dissertation, The University of New England, Armidale, Australia. 